\title{
At give ret, ret at give
}

En spidsformulering af hovedargumentet i denne artikel lyder, at en del af Derridas mest konsekvensrige etiktænkning stammer fra St. St. Blicher.

Artiklen vil i en vis forstand beskrive en cirkel i sin argumentation: Efter indledningsvist ganske kort at have introduceret til dekonstruktion og etik bl.a. via nedslag i nærværende Derrida-artikel "En vis umulig mulighed for at sige begivenheden” vil jeg først vise, hvordan dele af Kierkegaards tænkning og af Enten-Eller er langt mere inspireret af Blicher, end forskningen hidtil har vidst. Dernæst vil jeg introducere til et par ikke-fiktive tekster af Blicher, som handler om samme tema om uret, som de behandlede tekster af Kierkegaard. I anden halvdel af artiklen vil jeg diskutere Derridas Kierkegaard-eksegese, som den kommer til udtryk i Dødens gave. Jeg argumenterer for, at Derrida slutter med at stille spørgsmålet om der gives en ikke-religiøs, teleologisk suspension af det etiske. Med det spørgsmål går jeg tilbage til Blicher og dennes "Præsten i Vejlbye", som både kan læses med og som svar på spørgsmålet. Samlet handler det således om, hvad tre, fire senere tekster af Derrida (bl.a. "Lovkraft" og Dødens gave) om gave, ret og lov kan sige om to af de ti værker på den danske kanonliste og om en genlæsning af forholdet mellem disse sidstnævnte og deres forfattere.

\section{Dekonstruktion}

Velkendte anklager mod dekonstruktion lyder, at den ofte enigmatiske og ordspillende stil, der kendetegner mange dekonstruktive tekster, er obskurantistisk, paradoksdyrkende og useriøs, samt at dekonstruktion er uansvarlig, nihilistisk og uetisk. Så sent som i 1995 kan Newton i Narrative Ethics stille dekonstruktion og etik op som en (indrømmet forsimplet) modsætning (Newton 1995, 37). I dag, 14 år senere, er mængden af titler, som forbinder lige netop dekonstruktion og etik, overvældende. Blandt de utallige turns, som er blevet diagnosticeret gennem de senere år, er den etiske vending uden tvivl en af de kraftigste og mest betydningsfulde, og 
særlig kraftig har vendingen mod etik været inden for dekonstruktive og narratologiske cirkler. Man kan gætte på, at disse endnu mere end så mange andre teoretiske retninger har oplevet et legitimeringsbehov og har skullet forsvare sig mod anklager om verdensfjern, negativ nihilisme og gold, formalistisk klassifikation respektivt. Narratologiske teoretikere og dekonstruktivt inspirerede poststrukturalister trækker hver deres etiske linjer gennem teorihistorien. Dekonstruktive tænkere som Geoffrey Bennington med flere trækker via Derrida på en arv fra Levinas og Blanchot, mens narratologiske teoretikere som James Phelan og Dorothy Hale i en snart sagt bogstavelig forstand afsværger samme arv for i stedet at bekende sig til en linje, der gennem Wayne Booth går tilbage til Henry James. I The Company We Keep: An Ethics of Fiction fra 1988 beskriver Wayne C. Booth forholdet mellem bog og læser i venskabstermer. Booths bog bliver et gennemgående referencepunkt for en beskæftigelse med litteratur og etik i narratologien. ${ }^{{ }^{1}}$ Den bliver også i nogle henseender et kontrapunkt for dekonstruktive tilgange. Et eksempel herpå findes hos Derek Attridge, der som en opposition og tilføjelse til Booths beskrivelser skriver:

6 Rather than the familiar model of the literary work as friend and companion, sharing with the reader its secrets, I propose the work as stranger, even and perhaps especially when the reader knows it intimately. (Attridge 1999, 333)

Man kan bemærke, at Attridge i citatet for så vidt deler antagelsen om, at bøger og personer umiddelbart lader sig sammenligne og sammenstille. I det hele taget er en del dekonstruktive og narratologiske tilgange fælles om ofte relativt uproblematiseret at antage, at der er en direkte sammenhæng mellem en læsningens eller interpretationens etik og en etik i al almindelighed. Som Stefan Iversen har foreslået, kan man slagsordsagtigt angive forskellen mellem dekonstruktionens og narratologiens syn som forskellen på at betragte vennen som bog og bogen som ven.

Efter min mening overgeneraliserer den typiske narratologiske og den typiske dekonstruktive tilgang i hver sin retning ved oftest at forudsætte en slags "altid". Henholdsvis i form af "det stærke litterære kunstværk er altid i sidste instans opbyggeligt, sammenhængende, kohærent og afkodeligt på en måde, som udelukker en række læsninger, der ikke tager tilstrækkeligt hensyn til, hvad der faktisk står i værket" og: "det stærke litterære kunstværk rummer altid i sidste instans fremmedhed, gådefuldhed, og selvmodsigelser, der åbner det for læsninger, der ikke begår den fejl at forveksle interpretation med dechifrering."

Derrida på sin side tematiserer selv det påståede skel mellem en tidlig, tekstcentreret, verdensfjern dekonstruktion og en senere etisk, verdensorienteret, politisk dekonstruktion i teksten "Force of Law" (1989/1990/1994) ved at benægte skellet og opponere mod en forestilling om dekonstruktion som umoralsk og unyttig:

$6 f$ That is how I would like to employ myself here: to show why and how what one currently calls deconstruction, while seeming not to "address" the problem of justice, has done nothing else [...]. (Derrida 2002, 237) ${ }^{2}$ 
gelse om, at de nyere tekster af Derrida om demokrati, gæstfrihed osv. potentielt har meget at sige om kunst og litteratur. Lidt senere i "Force of Law" strammes skruen endnu et nøk i en nu berømt formulering:

46 Justice in itself, if such a thing exist, outside or beyond law, is not deconstructible. [...] Deconstruction is justice. (243, Derridas kursiv)

Der er altså langt fra tale om, at juridiske, politiske, moralske og sociale spørgsmål er ikke-dekonstruktible i al almindelighed. Netop det moralske og det sociale og endmere det politiske og juridiske udgøres af systemer, konventioner, love osv., som ikke alene kan, men i en vis optik må dekonstrueres. Modstillingen mellem retfærdighed og lov er vigtig. Der er her ikke tale om paradokstænkning eller om selvmodsigelse, men om et klart og operationelt skel: Lov er til forskel fra retfærdighed dekonstruktibel (242).

Den i dette Passage-nummer oversatte artikel "En vis umulig mulighed for at sige begivenheden" er i mange henseender paradigmatisk for den senere Derrida, og - endskønt ikke blandt de tungeste og indholdsrigeste - velvalgt som et minikatalog over flere af den sene Derridas interesseområder og fremgangsmåder. Artiklen fremstår let og henkastet og tilsyneladende dybt præget af sammenhængens mundtlighed og ekstemporalitet. Paradigmatisk er den også med sine mange paradoksformuleringer, der jo slår helt ud i titlens "umulige mulighed". Da Derrida efter de to indlagte forelæsninger af andre foredragsholdere går i gang med en forsøgsvis besvarelse af seminarets spørgsmål om, hvorvidt det er muligt at "sige begivenheden", så begynder han med at skelne mellem konstativer og performativer og fortsætter med at sige, "at sige begivenheden" ikke kan forstås som en "almindelig" performativ ("Når jeg siger, "jeg lover", beskriver jeg intet, jeg siger intet, jeg gør noget, det er en begivenhed" (23)). På den anden side kan "at sige begivenheden" heller ikke uden videre være en konstativ, eftersom konstativen altid vil komme efter og være gentagende og deskriptiv i forhold til begivenhedens singularitet og uforudsebarhed. Derfra bevæger Derrida sig over til en kortfattet diskussion af, hvordan f.eks. tv-mediet - selv der hvor det tilsyneladende blot re-præsenterer, beskriver og gengiver en begivenhed - i virkeligheden fungerer begivenhedsproducerende. Som en art pendant til denne semiskjulte kvasiperformativ, indleder Derrida den tætteste del af artiklen med at vende tilbage til den egentlige performativ med ordene:

64 Dette sætter os naturligvis på sporet af en anden dimension i en sigen af begivenheden, der fremstår som egentligt performativ: alle disse sproglige former, hvor talen ikke er et spørgsmål om at oplyse, at rapportere noget, at formidle, at beskrive, at konstatere, men at frembringe ved talen [...]. Lad os tage tre eller fire eksempler.

Det gøres ikke klart, hvordan man skal opfatte den tilsyneladende flagrante modstrid med det tidligere udsagn om, at performativen ikke kan være "at sige begivenheden" og karakteristisk for den ekstemporale form følger ikke tre eller fire, men fem eksempler. Endvidere er kun ét af disse et eksempel på en tale- 
handling og maksimalt ét et eksempel på at sige begivenheden.

De fem er: tilståelse, gave, tilgivelse, opfindelse/opfindsomhed og gæstfrihed. Om tilståelsen gælder, at den ikke kan være rent deskriptiv og informerende, men også må indeholde et moment af performativ for at fungere som tilståelse, om gaven, at den for at være en virkelig gave må være placeret hinsides økonomi og derfor i sin radikale form gives uden at hverken giver eller modtager ved det, om tilgivelsen, at den virkelige, radikale tilgivelse må være en tilgivelse af det utilgivelige, idet det tilgivelige netop ikke kræver nogen særlig bevægelse eller vilje, da det netop er tilgiveligt, om opfindelse/opfindsomhed, at den ikke blot må være en aktualisering af en potentialitet eller mulighed, der i forvejen foreligger, men må opfinde, hvad der er ikke-muligt, og endelig om gæstfriheden, at den må åbne sig ikke alene for det totalt uventede, men endog for at modtage det, som man er ude af stand til at modtage, idet det ventede, overkommelige, modtagelige ikke kræver egentlig, radikal gæstfrihed.

Fælles for eksemplerne er ikke en relation til seminarets tema eller en status af performativer, men derimod, at de på hver sin måde i deres radikale form, i Derridas udlægning, kun er mulige som umulige. Den gentagne formel er af typen " $\mathrm{X}$ er kun virkelig X, når og hvis X er ikke-X" eller anderledes formuleret: "X er kun mulig, når X er umulig”. I mange tilfælde må man, hvis man ikke blot vil placere eksemplerne hinsides rationalitet og intelligibilitet, forsøge at forstå dem i retning af "X er kun virkelig X i henseende til Y, når X er ikke-X i henseende til Z".

Selv om passagen $i$ en vis forstand er en fortættet og eksemplarisk tour de force i ekstemporal og karakteristisk radikalisering af velkendte begreber og insisteren på ikke-simplicitet, så forekommer det mig alligevel, at de savner den tyngde og prægnans, som de har i andre tekster, hvor de udvikles af minutiøst omhyggelige nærlæsninger (af især Benjamin i Force of Law og af bl.a. Kierkegaard i Dødens gave osv.).

Udviklingen af gavens paradoks i artiklen bygger i høj grad netop på Kierkegaard-analyserne i Dødens gave, og selve formlen vil vi genfinde i den særlige figur for etik og pligt, som Derrida læser ud af Kierkegaard og Kant, idet han konkluderer, at kun ved at tilsidesætte sin pligt, kan man begynde at opfylde sin pligt. Hvad Blicher siger om dette fænomen og vice versa, kommer vi til i fjerde og femte afsnit. Først skal vi se, hvordan Kierkegaard - til tider åbenlyst, til tider kryptonomisk - angiver Blicher som sin kilde.

\section{Kierkegaard og Blicher}

Allerede i Kierkegaards første udgivne værk, Af en endnu Levendes Papirer, der er en kritik af H.C. Andersen som romanforfatter, omtales Blicher hyppigt og positivt. Blicher fungerer flere steder som det positive modbillede til Andersen, og Kierkegaard holder Blicher endog særdeles højt (se bl.a. Kierkegaard 1838, 28 og 32). Blicher kaldes for "hiin Røst i Ørkenen" (27f), og hans noveller omtales som

(f [...] et for Phantasien udslagen folkelig-idyllisk af mægtige Kornmod gjennemlynet Billede - en dyb poetisk Stemning, indhyllet i Umiddelbarhedens Taageslør (28). 
Der er god grund til at tro, at det er herfra Blicher med stolthed henter titlen på sin Kornmodn fra året efter, 1839. ${ }^{3}$ I Kornmodn findes førsteudgaven af "Skytten paa Aunsbjerg", som vi straks skal få at se, hvordan Kierkegaard bringer ind i sit forfatterskab. Man fristes til at sige, at ligeså uretfærdig en dom Kierkegaard synes at fælde over Andersen, lige så stærk og præcis er hans læsning og karakteristik af Blicher. Sjovt nok er det, som om hans egen metafor om forholdet mellem de to understreger en vis form for selvvalgt forvrængning. Det hedder nemlig således efter den meget rosende omtale af Blicher:

46 Efter saaledes at have givet vor Kikkert de behørige Udtræk, maae vi bede de ærede læsere at lade Øiet følge med, naar vi rette den hen på vor egentlige Gjenstand: den af en temmelig betydelig literair Virksomhed ikke ufordeelagtigt bekjendte Digter Hr. H. C. Andersen, idet vi derved haabe os sikkrede mod den illusoriske Opfattelse og de Sandsebedrag, som det blotte Øie ofte er udsat for. (28)

På den ene side forstår man vel, at Blicher gøres til den målestok, med hvilken anden digterisk virksomhed skal måles. På den anden side virker det mildt kuriøst at mene sig sikret mod synsbedrag ved først at indstille kikkerten på én ting, og dernæst rette den mod noget andet, som iagttages gennem denne (forhånds)indstilling; omtrent som hvis man fandt skovbrynets træer sært forvrængede gennem en kikkert, der havde stillet skarpt på det fjerne bjerg.

Kierkegaard siger - på én gang præcist og enigmatisk - om Blichers noveller:

4 I ethvert Tilfælde er ogsaa her en Eenhed, der i sin Umiddelbarhed betydningsfuldt peger ind i Fremtiden, og som nødvendigviis maa gribe Samtiden meget mere, end den har gjort, og derved maaske komme til at virke heldbringende for den prosaiske Maade, paa hvilken Politiken hidtil er blevet behandlet. (28)

Også i papirerne omtaler Kierkegaard flere steder Blicher meget positivt. Interessant, sigende og rørende er bl.a. et lille digt, som Kierkegaard komponerer til Blicher:

Sub rosa

til S. S. Blicher

i anledning af hans Naturconcert

Wenn ich ein Vöglein wär,

Und auch zwei Flüglein hätt, Flög ich zu Dir;

Weils aber nicht kann sein,

Bleib ich allhier. (Kierkegaard 1968, 2A, 259)

Kierkegaard nævner ikke titlen på naturkoncerten, Trækfuglene, der gør hans fuglefantasi apropos. Ligeledes udelader eller substituerer han i sidste vers dét ord, som rimmæssigt, metrisk og semantisk ville afrunde digtet, nemlig ordet "allein”. Et afsluttende vers, der i stedet lød "Bleib ich hier allein" ville afrunde digtet på noget ba- 
stant, men også markant vis, mens det valgte, i stedet for at sammenstille "sein" og "allein" som afsluttende parrim, lader "Dir" og "hier" være på én gang samlede og adskilt af henholdsvis rim og vers, hvorved digtets udgang bliver kendetegnet af en særegen forbliven sammen hver for sig. Det udtrykte forhold til Blicher overskrider tydeligvis respektfuldhed og må snarere karakteriseres som fortrolig kærlighed.

Én ting er imidlertid Kierkegaards utvetydige valorisering af Blicher, når han omtales, noget andet er, at Blichers indflydelse på og betydning for Kierkegaards forfatterskab er væsentlig større end hidtil antaget.

I Anlangendes et menneske nævner Langballe flere af de steder, hvor Kierkegaard omtaler Blicher ${ }^{4}$ og fortsætter med at skrive, at han mener, at "Eneboeren på Bolbjerg" danner forbillede for Victor Eremita hos Kierkegaard i Enten-Eller. At der er tale om inspiration til navnevalget synes at være en velbegrundet antagelse, og Langballe skriver da også, at udgiveren Victor Eremita daterer de fundne papirer til 1834, som netop er året, hvor "Eneboeren på Bolbjerg" udkom (Kierkegaard 1843a, 16). Mere tvivlsomt er det, om "[...] hele Kierkegaards værk er bygget over [...]" "Eneboeren på Bolbjerg”, som Langballe hævder s. 423. Særdeles skeptisk er jeg også over for Langballes antagelse af, at de tre stadier æstetisk, etisk og religiøs hos Kierkegaard skulle være formet efter Christian Eneboers udvikling i samme novelle; dertil fremstår de mulige stadier hos hovedpersonen i Blichers novelle alt for umarkerede.

På den ene side er inspirationen således næppe så direkte, at hele Kierkegaards værk er determineret af Blicher, men på den anden side er inspirationen heller ikke begrænset til én enkelt Blichertekst.

Langballe bemærker flygtigt, at den sekretær, hvori papirerne findes af Victor Eremita, "[...] giver mindelser om skytten på Aunsbjerg, men vel også kan have andre inspirationskilder" (424). Det er i allerhøjeste grad rigtigt, at beskrivelsen hos Kierkegaard giver mindelser om den hos Blicher, men lighederne fortsætter langt derudover.

Den gådefulde hovedperson i "Skytten paa Aunsbjerg" lyder det danske navn Vilhelm og er i novellen etikeren par excellence. Der er mange gåder i novellen og mange nøgler til deres løsning. Helt mod slutningen af novellen erfarer vi, at endnu en gåde består i, hvordan Vilhelm, der i virkeligheden synes at være fransk adelsmand, er havnet som skytte i Danmark. Denne Vilhelm har i en forudanelse om sin død efterladt et papir til etatsråden, hvoraf det fremgår, at der findes en pakke breve med yderligere oplysninger:

Uf [...] endelig findes i et hemmeligt Gjemme en liden Pakke Breve [...]. For at finde det hemmelige Rum, behøves kun at trykke med en spids Syl." - længere var intet læseligt, da det var overslaaet med Blæk. - "Det gjorde Katten" sagde den Gamle, "den sprang op paa Bordet til mig, som jeg sad og læste, og væltede Blækhuset; men forneden seer Du, at han har underskrevet sig Guillaume de Martonniere. Han har altsaa været Adelsmand; men Skuffen kunde jeg ikke finde, hvor ofte jeg end ledte efter den." - "Men har De da Skatollet?" spurgte jeg. - "Ja vel har jeg det, for jeg kjøbte det paa Auctionen, jeg lod holde efter ham. Jeg har ikke kunnet beslutte mig til at hugge det istykker, saameget mindre, som der slet ikke er Tegn til noget hemmeligt Gjemme; thi alle Rum synes mig at være lige 
store, og at strække sig lige ind til Bagklædningen. Har han ejet de omtalte Documenter, maae han have havt dem et andet Sted. Saaledes endte han; og jeg maa ligeledes ende. Da han døde, og hans Efterladenskaber bleve solgte, var jeg langtfraværende, og veed ikke hvor dette Skatol blev af; ligesaalidt, om det er til endnu. Men skulde dette være Tilfældet, og Nogen, som læser disse Blade, er vidende herom, da kunde der skee mig - og maaskee Flere - en Tjeneste ved Underretning herom; thi jeg nærer den Overbeviisning: at de nævnte Breve dog maae findes i dette Bohave, og vilde rimeligviis give Oplysning om Guillaume de Martonnieres tidligere Liv og Hændelser, og vise os, hvorledes denne franske Adelsmand er kommen til at ende sine Dage som simpel Skytte hos en jydsk Herremand. (Blicher 1839, 47)

Det er således aldrig lykkedes hverken etatsråden eller fortælleren at finde rummet eller papirerne. Enten-Eller indledes i forordet med fortællingen om, hvordan Victor Eremita på sin side uventet får nogle papirer i hænde. Vi hører om hans forelskelse i en "secretair" hos en marskandiser; om hvordan han til sidst køber den, og endelig om, hvordan han, en dag hvor han ikke kan få en skuffe op, slår til den med en "Haandøxe". Dermed kan man sige, at "gjemmet" kommer for en dag, netop fordi han kommer til at gøre, hvad etatsråden ikke kunne beslutte sig til: "at hugge det istykker".

En hemmelig dør springer op, og derefter hedder det:

46 Denne lukkede for et Gjemme [...]. Her fandt jeg til min store Overraskelse en Masse af Papirer, de Papirer, der udgjøre den foreliggende Skrifts Indhold. [...] den ene Deel indeholdt en Mængde større eller mindre æsthetiske Afhandlinger, den anden bestod af to store Undersøgelser og én mindre, alle af ethisk Indhold, som det syntes, og i Brevform. (Kierkegaard 1843a, 12)

Victor Eremita fortsætter: "Hvad den anden, Brevskriveren, angaaer, da erfarer man, at han har hedt Vilhelm" (13). I både Blichers tekst fra 1839 og Kierkegaards fra 1843 har etikeren Vilhelms breve altså været opbevaret i et hemmeligt "gjemme". De æstetiske afhandlingers forfatter kalder Victor Eremita A, og de etiske breves kalder han B, hvilket sidstnævnte bogstav Blicher i øvrigt særdeles ofte signerede sine tekster med. Vi har altså en rækkefølge, hvor Kierkegaard i 1838 har læst Blichers noveller og bruger en betegnelse om dem, som Blicher overtager i sin samling fra 1839, hvori "Skytten paa Aunsbjerg" optræder, hvorefter Kierkegaard i 1843 versionerer en tilvejebringelse af Vilhelms bortkomne breve; dernæst, i 1844 vælger Blicher selv at lade brevene se dagens lys i sin egen fortsættelse, "Guillaume de Martonniere".

Én ting er den fiktive person Vilhelm og hans fiktive breve, samt opdelingen i den æstetiske A) og den etiske B), en anden er, at Enten-Eller ud over de to dele og i tillæg til forordet også rummer et appendiks, eller som det kaldes, et "Ultimatum". Dette ultimatum er kommet som et personligt brev til Vilhelm og indeholder en prædiken med titlen "Det opbyggelige der ligger i den Tanke, at mod Gud have vi altid Uret". Brevet og prædikenen, som det er nærliggende at læse som et tentativt C), der repræsenterer det religiøse, er kommet fra en ven, om hvem det hedder: 
4 For en fire Aar siden blev han puttet ind i et lille Præstekald paa den jydske Hede. [...] "Den jydske Hede," siger han, "er dog ret en Tumleplads for mig, et Studerekammer uden Lige [...]." (Kierkegaard 1843a, 310)

Få læsere vil vist kunne undgå at genkende Blicher i dette portræt. Hvad mere er, synes det overordentligt sandsynligt, at Kierkegaard må have læst førsteudgaven af Blichers "Selvbiografi" fra 1840, idet han skriver om brevsenderen fra heden:

16 Videnskaberne fængslede ham, men Examens-Mand blev han ikke, Han drev det ikke til mere end haud illaudabilis til theologisk Attestats. (309f)

Hos Blicher hedder det nemlig i den særegne tredjepersonsomtale af ham selv:

I Foraaret 1809 gik B. op til Attestats, og erholdt Karakteren "Laudabilis, inprimis ob spe6 cimen scriptum." Aaret efter prædikede han for Dimiss, og fik Laud.; men for Cathekisering kun et Haud; hvilket baade er det første og det sidste han har erholdt for nogen Disciplin. (Blicher 1846 [1840], XIII)

Prædikenen, der udgør det afsluttende ultimatum i Kierkegaards hovedværk, beskrives altså via adskillige henvisninger som en tekst, der har Blicher som egentlig forfatter. Og det er ikke med ringe vægt, at de afsluttende ord lægger op til den:

6 Han har i denne Prædiken grebet, hvad jeg har sagt, og hvad jeg gjerne vilde have sagt Dig; han har udtrykt det heldigere, end jeg seer mig istand til. Tag den da, læs den, jeg har Intet at tilføje, uden at jeg har læst den, og tænkt paa mig selv, læst den, og tænkt paa Dig. (310)

Der er mange grunde til, at tanken om Blicher som forfatter af en prædiken om det opbyggelige i tanken om altid at have uret mod Gud absolut ikke er malapropos. Igennem hele Blichers forfatterskab - det fiktive såvel som det ikke-fiktive og det midt imellem - flyder en dyb skepsis over for forestillinger om med sikkerhed at have ret. Konsekvenserne undersøger vi i fjerde afsnit. Forinden vil vi vende os mod Derridas behandling af et andet, men nært beslægtet spørgsmål i hans læsning af Frygt og Bæven.

\section{Derrida og Kierkegaard}

Enten-Eller begynder og slutter ved Blicher i henholdsvis forord og afsluttende ultimatum. Han er, fristes man til at sige, værkets alfa og omega. Senere samme år udkommer Gjentagelsen og Frygt og Bæven på samme dag i oktober 1843. I Frygt og Bæven er spørgsmålet ikke længere alene om det opbyggelige ved at have uret for Gud, men om der gives en decideret suspension af det etiske. Fortælleren, Johannes de silentio, priser Abraham som troens ridder, der aldrig tvivler, men tror i kraft det absurde, da han på Guds bud drager ud for at ofre sin eneste søn på Morija-bjerget. 
Silentio beskriver, hvordan Abraham etisk set er morder af den mest modbydelige slags, idet han sætter sig ud over lov, ret og det almene for troende at følge Guds bud. Abraham er i en vis forstand uforståelig, også for de silentio. Her er det ikke ærindet at referere eller deltage i diskussionerne om det potentielt stærkt problematiske i denne overskridelse af det etiske hos Levinas m.fl. I stedet vil jeg blot eksemplificere med et kort citat fra Jonathan Littels prisbelønnede De velvillige, hvor den intellektuelle amtschef Otto Ohlendorf bruger netop Kierkegaards værk som argument for nødvendigheden af at tilsidesætte etiske hensyn:

4f [...] hvad angår os som har fået pålagt den tunge byrde at gennemføre denne opgave, er det vores pligt mod vores folk, vores pligt som sande nationalsocialister, at adlyde. Selv om lydighed er den kniv der slagter menneskets vilje, som den hellige Josef af Cupertino sagde. Vi bør acceptere vores pligt på samme måde som Abraham accepterer det utænkelige offer af sin søn Isak der kræves af Gud. Har de læst Kierkegaard? Han kalder Abraham troens ridder der ikke blot skal ofre sin søn, men også og især sine etiske ideer. Det er det samme for os, ikke sandt? Vi bør fuldbyrde Abrahams offer. (Littell, 211)

Ohlendorf skaber således en direkte forbindelse mellem jødernes og nazisternes holocaust. Og beskriver det som en "pligt" at gå hinsides etikken. I Derridas Kierkegaard-læsning stilles spørgsmålet om et etikkens hinsides omtrent modsat, som et spørgsmål om en pligt til ikke at følge sin pligt. Vi genfinder altså figuren ovenfra. Det gælder pligt, som det gjaldt bekendelse, gave, tilgivelse, opfindelse/opfindsomhed og gæstfrihed, at den kun er mulig som umulig, eller præcisere talt, at man kun ved at overskride sin pligt kan gøre sin pligt. Og det gælder denne som hine, at det handler om en retfærdighed, der går hinsides økonomi.

Kernen i Derridas udlægning af Kierkegaards behandling af Abraham sammenstiller Kierkegaard og Kant, idet begge rejser spørgsmålet om pligt som et spørgsmål om dens overskridelse. Forskellen består i, at Kierkegaard gør det i relation til Gud, Kant i relation til Loven. I Derridas konsekvensrige parafrase:

4f Den absolutte pligt over for Gud kan ikke antage den form for almenhed, der kaldes pligt. Hvis jeg adlyder min pligt over for Gud (og det er den absolutte pligt) alene $i$ kraft af pligten selv, står jeg ikke i forhold til Gud. For at gøre min pligt over for Gud selv, må jeg ikke handle af pligt, af denne form for almenhed, der altid er mæglende og kommunikerbar, og som vi kalder pligt. Den absolutte pligt, som forbinder mig til Gud selv, i troen, må findes hinsides og gå mod enhver pligt, jeg har: "Pligten bliver til Pligt ved at henføres til Gud, men i Pligten selv træder jeg ikke i forhold til Gud" (SV 5, s. 63; p. 159). Kant forklarede, at det at handle moralsk var at handle "af pligt" og ikke blot "i overensstemmelse med pligten". Kierkegaard ser det at handle "af pligt" i lovens universalisable betydning som en forsømmelse af ens absolutte pligt. Det er her, at ens absolutte pligt (over for Gud og i troens singularitet) indebærer en form for gave eller ofring, som peger mod en tro, der er hinsides både gæld og pligt, hinsides pligten som en form for gæld. (Derrida 2007b, 81)

Kantpassagen, som Derrida henviser til, er formentlig den følgende fra Kritik der praktischen Vernunft: 
6 Pligtens begreb kræver altså ved handlingen en objektiv overensstemmelse med loven, men ved handlingens maksime en subjektiv agtelse for loven, som den eneste måde, viljen kan bestemmes gennem loven. Og på dette hviler forskellen mellem bevidstheden om at have handlet pligtmæssigt og af pligt, dvs. af agtelse for loven, hvoraf den første (legaliteten) også er mulig, hvis det blot er tilbøjeligheder, der var viljens bestemmelsesgrunde, mens derimod den anden (moraliteten), den moralske værdi, udelukkende må sættes deri, at handlingen sker af pligt, dvs. blot for lovens skyld. (195 [Kant s. 95])

I spil her er altså på én gang spørgsmål om etik, ret, lov og Gud. Kierkegaard stiller, som det vil være mange bekendt, i Problema I spørgsmålet "Gives der en teleologisk Suspension af det Ethiske?" (51):

46 Troens Paradox er da dette, at den Enkelte er høiere end det Almene, at den Enkelte [...] bestemmer sit Forhold til det Almene ved sit Forhold til det Absolute, ikke sit Forhold til det Absolute ved sit Forhold til det Almene. Paradoxet kan ogsaa udtrykkes saaledes, at der er en absolut Pligt mod Gud; thi i dette Pligtforhold forholder den Enkelte sig absolut til det Absolute. Naar det da i denne Forbindelse hedder, at det er Pligt at elske Gud, saa siges dermed noget Andet end i det Foregaaende; thi er denne Pligt absolut, saa er det Ethiske nedsat til det Relative. Heraf følger dog ikke, at dette skal tilintetgjøres, men at det faaer et ganske andet Udtryk, det paradoxe Udtryk, saaledes at f. Ex. Kjærlighed til Gud kan bringe Troens Ridder til at give sin Kjærlighed til Næsten det modsatte Udtryk af hvad det Ethisk talt er Pligt. [...] Dette Paradox lader sig ikke mediere [...]. (Kierkegaard 1843c, 64f)

Første del af Derridas læsning består i at følge Kierkegaard helt ud i det radikale troens paradoks, der sætter den enkelte over det almene i den absolutte pligt mod Gud. Paradokset er umedierbart hos Kierkegaard og i Derridas læsning, hvor en underlæggen sig det almene eller "universalisable" irreducerbart fører til en forsømmelse af den absolutte pligt. Den absolutte pligt, troen og religiøsiteten er således ikke vehikel for almen moral, men tværtimod dennes overskridelse og modsætning.

Men i den anden del af Derridas læsning gøres bevægelsen nu i en vis forstand tilbage igen; fra det singulære og absolutte til det - om ikke almene så - almindelige. Det sker ad to veje, idet han udlæser to generaliseringer af Kierkegaards læsning af Abraham som det singulæreste af alle tilfælde. Den ene kalder Derrida ligefrem "den mest hverdagsagtige og mest almindelige erfaring af ansvar" (85). Det er den mest kommenterede (se fx kapitlet "An everyday impossibility" i Attridges The Singularity of Literature samt Attridge 1999), og Derrida bruger mere end ti sider på den. Den består i, at man uvægerligt altid ofrer nogle for at redde/give nogle andre:

4 Der er også andre, et uendeligt antal, de andres utallige almenhed, til hvem jeg bør bindes med et lignende ansvar, et alment og universelt ansvar (som Kierkegaard kalder det etiske). Jeg kan ikke svare kaldet, begæringen, forpligtelsen, end ikke en andens kærlighed, uden at ofre den anden anden [l'autre autre], de andre andre [les autres autres]. (86) 
På samme måde fortsætter Derrida med at vise, hvordan man altid ubodeligt forsømmer sin pligt på en række områder ved at gøre sin pligt på ét osv. Det kan være sandt og oplysende nok, men er for mig at se samtidig klart det mest uspændende, idet det som uundgåeligt grundvilkår synes aldeles uden konsekvenser. Langt mere spændende - og problematisk - er den anden generalisering af den absolutte pligt, som Derrida anslår indledningsvist over nogle få linjer, hvor han om Abrahamfortællingen siger:

46 Denne fabels moral er moralen selv [...]. Det absolutte ved pligten og ansvaret forudsætter, at man, på én gang, angiver, forkaster og transcenderer al pligt, alt ansvar og alle menneskelige love. [...] Den absolutte pligt fordrer, at man opfører sig uansvarligt (ved troløshed og forråd) altmedens man anerkender, stadfæster og bekræfter selve det, man ofrer, nemlig etikken og de menneskelige ansvar. I ét ord: etikken må ofres i pligtens navn. Det er en pligt ikke at respektere, af pligt, den etiske pligt. (84)

Tankegangen udfoldes ikke yderligere i denne retning og kan næsten ikke gribes ud fra denne passage alene, men skal formentlig ses i lys af en kantiansk tankegang som den, Derrida også henviste til i citatet ovenfor fra s. 81, og som han yderligere generaliserer og radikaliserer senere i "Lovkraft":

4 Hvis jeg slår mig til tåls med at applicere en retfærdig regel, uden retfærdighedens ånd og uden på en eller anden måde for hvert tilfælde at opfinde [inventer] reglen og eksemplet, ville jeg måske være i ly for kritik, under rettens beskyttelse, jeg ville agere i overensstemmelse med den objektive ret, men jeg kunne ikke være retfærdig. Jeg ville, som Kant ville have sagt, handle i overensstemmelse med pligten, men ikke af pligt eller af respekt for loven. (Derrida 2007a, 226)

Jo mere man insisterer på, at en etik, der fortjener sit navn, aldrig kan nøjes med at henholde sig til regler, der kan almengøres og konsulteres, jo tættere kommer man på at måtte sige, at den enkelte i det enkelte tilfælde må overskride reglen og den konsensuale etik, hvis han ikke blot vil være en bogholder, der søger alibi. Derrida følger altså Kierkegaard i en radikal modstilling af det almene og det absolutte, men hvor Abrahams suspension af det etiske hos Kierkegaard følger af en absolut tro og af kærlighed til Gud, dér kan man sige, at Derrida søger at vise, at det etiske i sig selv er hjemsøgt af sin egen overskridelse eller suspension, idet det på flere niveauer gælder, at kun den, som ikke blot gør sin pligt, gør sin pligt. Eller at pligtens opfyldelse i egentlig forstand kun er mulig, hvor det ikke er muligt at gøre sin pligt. Mere om dette i artiklens sidste afsnit, hvor jeg vil vise, på hvilken måde Derrida således åbner for spørgsmålet om der gives en non-religiøs, teleologisk suspension af det etiske.

Det spørgsmål er dybt forbundet med spørgsmål om ret over for retfærdighed og om viden over for tro. Med disse spørgsmål in mente og med etikkens ofring på etikkens eget alter som den på én gang mest singulære og mest generelle fordring vender vi nu tilbage til Blicher. 


\section{Blicher}

I sin "Prædiken, holdt i Randlev og Bjerager Kirker" er Blichers udgangspunkt lige netop en etisk tragedie, der skyldes en far, som har efterlignet Abraham, ikke ved troen, men ved gerningen:

64 Idag, mine Venner! idag modtager Jorden i een Grav tre Brødres Legemer, som for nogle faa Dage siden vare beboede og oplivede af glade og uskyldige Sjæle. [...] De vare døde! alle paa eengang! - Hvorledes vare de døde! - Myrdede! - Hvo vilde myrde Uskyldigheden? myrde den sovende Uskyldighed?! Hvis Vrede - hvis Hævn - hvis Rovgjærrighed - hvis Blodtørst kunde disse venlige Engle opvække? - Hvo var den skumle Morder, der kunde drage Kniven imod de sødt slumrende Smaae?! Hvis var den Haand, der ikke tabte Staalet ved Synet af sovende Brødre [...] var han betaget af vanvittig Raserie?! Nei med fuld Bevidsthed, med koldt Overlæg slagtede han dem [...]. Vi have hørt om Konger og Regentere, som have ladet deres Sønner henrette; men disse have været voxne - stundom Forbrydere - stundom forførte, bagtalte - stundom deres Fædres Medbeilere, stundom deres Efterstræbere. Men at en Fader med Forsæt og Overlæg myrder sine umyndige, uskyldige Børn - at han, deres Livs Ophav, selv tilintetgjør det; han, som skulde lukke Døren for Morderen, selv trækker Kniven - han, til hvem deres eneste Haab, Tilflugt, Tillid, Kjærlighed her i Verden staaer; at han bortstøder de Arme, der udstrække sig mod ham, og - støder Staalet i de Hierter, der banke af Ømhed, af Ømhed for ham - Brødre! det er en underjordisk Rædsomhed, en Utroelighed [...]. (Blicher 1920, bd 4, 231f)

Udeladelsen af det ene, berømte fortilfælde fra Biblen er på én gang bemærkelsesværdig og forståelig. Bemærkelsesværdigt er det ligeledes, at Blicher gang på gang omtaler handlingen som en ofring:

64 Men, til hvilken Afgud, hvilken Mørkheds Aand, har han offret Guds bedste kjæreste Gave? (232)

Og senere:

$6 f$ Fremmedes Taarer randt paa deres blege Kinder, og fremmede Hænder bare dem smykkede, som Offerlam til Jorden [...]. (234)

Og igen:

46 Deres jordiske Fader offrede dem til sit forhærdede Sinds Afguder [...]. (234)

Det sidste citat giver os en nøgle til forklaring: Der er tale om en ofring, men til afguder. Faderen har ikke ofret, hvad han elsker mest, og hvad der for ham er "Guds bedste kjæreste Gave", men ofret til en afgud, fordi han er kommet i ulykke af at elske det forkerte højere: 
46 Ak! havde denne Rasende, hvis Navn jeg ikke vil nævne, villet betvinge den Pengegjerrighed, der bragte ham til at elske Guldet over Alt, der bragte ham til, at fortvivle ved Tabet af jordisk forfængeligt Gods, som Ild kan fortære, og Tyve berøve os - at foretrække det for de himmelske Skatte, som "ingen Tyv kan stjæle, ingen Møl eller Rust kan fortære" [...]. (235f)

Blicher citerer her skjult Matthæusevangeliet. Derrida citerer - med henvisning samme sted og ekspliciterer forholdet mellem økonomi og etik:

4f Saml jer ikke skatte på Jorden, hvor møl og rust fortærer, hvor tyve bryder ind og stjæler. Men saml jer skatte i himlen, hvor hverken møl eller rust fortærer, og hvor tyve ikke bryder ind og stjæler. For hvor din skat er, dér vil også dit hjerte være.

Hvor er hjertet? Hvad er hjertet? Hjertet vil således, i fremtiden, være dér, hvor du har reddet en sand skat; den skat der ikke er synlig på jorden, den hvis kapital akkumuleres ud over det synliges økonomi eller det jordisk sanseliges økonomi, dvs. den korrumperede eller korrumperlige økonomi, som er sårbar over for møl, rust og tyve. (Derrida 2007b, 115)

Ud af tragedien advarer Blicher for det første mod at tro, at den slags hændelser sker efter Guds vilje eller fordi en djævel forfører - de er resultater af menneskers egen, frie vilje, siger Blicher. For det andet tager han den advarsel af forbrydelsen, at enhver via sine handlinger og valg i forhold til morderen kan have sin mindre eller større andel i tragedien, samt at det ikke kan retfærdiggøre eller trøste nogen, at de ikke er en lige så stor synder som barnemorderen. Det eneste gran af opbyggelighed, der er ved tragedien - således kan man parafrasere slutningen på prædikenen - er, at den ved sit eksempel viser, at mennesket ikke bør stole på sig selv, men derimod finde opbyggelighed i ikke at have ret for Gud:

64 Værer da formanede Hver og Een, at I, opvakte ved dette forfærdelige Exempel, aldrig stole paa Eder selv, eller paa Eders egen Styrke! [...] Sikkerhed er Dydens træskeste Fjende [...]. Visselig, ethvert Menneske er idel Forfængelighed, i hvor fast han end staaer. Men Herren er min Styrke og mit Skjold; mit Hjerte haver forladt sig paa ham, og jeg er bleven hjulpen, Amen. (238)

Selv-sikkerhed nedbryder, mens uretsforvisning opbygger, fremgår det af Blichers prædiken fra 1817. Uigenkaldeligheden, hvis man tog fejl og ikke havde ret, er også en af flere årsager til, at Blicher er en inkarneret modstander af dødsstraf. Inden vi slutter med at se, hvordan problemstillingen gestaltes litterært i "Præsten i Vejlbye", vil jeg kort vise, hvordan Blicher med ganske eksplicit dekonstruktive midler i sin egen læsepraksis demonstrerer, hvordan en rets-tænkning, der mener at kunne være sikker på at have ret, bryder sammen i selvmodsigelser:

I 1813 var Friedrich Buchholtz' skrift Moses og Jesus eller om Jødernes og de Christnes intellektuelle og moralske Forhold blevet oversat til dansk. Læsningen heraf foranledigede Blicher til samme år at udgive en ikke helt lille, men i dag temmelig ukendt 
artikel, ${ }^{5}$ som rummer hans reaktion på Buchholtz’ bog, som man vist i dag roligt kan tillade sig at kalde et antisemitisk angreb. ${ }^{6}$ Det er imidlertid netop ikke Blichers strategi at gribe til sådanne karakteristikker. I stedet er Blicher helt fra begyndelsen bevidst om, at der er to former for retfærdighed på færde, og at de er uløseligt forbundne: Han kan i sin reaktion på Buchholtz' angreb på jøderne kun forsøge at yde jøderne retfærdighed, hvis det ikke mislykkes ham at yde skriftet retfærdighed. Blicher ønsker at vise, at Buchholtz på mange - ja næsten alle - punkter tager fejl, men ikke at gøre det ved at angribe ham med udefrakommende domme. Blicher undgår helst at gøre sig til antagonistens antagonist og hævder endog, at han, da han kort tid forinden udgav "Bør Jøderne taales i Staten?”, “[...] ingen Modstander kiendte [...]" (Blicher 1813, 35). I stedet for at tænke i agonistiske kategorier skriver Blicher:

6 Min Hensigt var ikke at fremstaa som Jødevæsenets Talsmand [...]. Jeg vilde ikke frikiende, ikke fordømme; men lede til en human og upartisk Kritik [...]. (35 - kursivering tilføjet)

I fors $\varnothing$ get på at opholde sig i denne mellemposition, hvor han på den ene side ønsker at gøre opmærksom på, hvad han anser for uretfærdigt og fejlagtigt ved Buchholtz' fremstilling af jøderne, men på den anden side ikke ønsker at fremskrive et positivt modbillede eller at blive en "Talsmand", anvender Blicher en vifte af strategier, som alle tager sigte på, at Buchholtz' værk skal vederfares retfærdighed. Derfor $\emptyset n s k e r$ Blicher naturligvis heller ikke, at folk ikke skal læse det. Tværtimod ønsker han "[...] at man under Læsningen af denne Bedømmelse stedse ville lægge det [Buchholtz” værk] ved Siden” (36).

Allerede en side tidligere, helt i begyndelsen af artiklen, har Blicher indledt med en subtil manøvre:

64 Men ere disse sande [Buchholtz' resultater], da Farvel Tro paa Dyd og Forsyn; da Farvel daarlige Indbildning om Menneskets Perfectibilitet! Her er et heelt Folk, som [...] aldrig skal kunne hæve sig over Dyrene [...]. (36)

Kort sagt: At underordne jøderne de kristne på den måde, som det sker hos Buchholtz, er i sig selv ukristent. Med stadig insisteren på at det vigtige er, at læseren læser, hvad Buchholtz skriver, i højere grad egentlig, end hvad Blicher skriver, fortsætter Blicher med at søge at vise læseren det paradoksale i den måde, hvorpå Buchholtz behandler spørgsmålet om netop "Paradox" og at fremstille "[...] de mange - med Tilladelse - Paradoxer, der findes i dette splinterny Værk" (38). To sider senere er det igen de indre modsigelser i Buchholtz' værk, som ønskes fremdraget: "Er Contradictio in Adjecto et Fortrin [som Buchholtz synes at mene], saa besidder Forfatteren dette i høj Grad, som siden skal vises" (40).

Endelig, i direkte forlængelse af denne tilgang, fremstiller Blicher hele sin gennemgående argumentationsstruktur som en veritabel Abbau. Netop hvis man tager dets egne grundstene og formuleringer for pålydende, falder Buchholtz’ værk sammen, mener Blicher: 
46 Forfatteren fremstiller os nu den Hovedhiørnesteen, hvorpaa hans Bygning hviler; kunne vi rokke denne Steen, da erklærer han Bygningen for nedreven: Men - hedder det - hvis man endelig skulde angribe hans Skrivt fra dets Indholds Side, saa giør han i forvejen opmærksom paa: at det beroer paa at giendrive følgende Sætninger, som ere ligesom Islætten i hans Væv. (39) ${ }^{7}$

Karakteristisk er i den forbindelse Blichers indledende, prospektive løfte:

46 [...] aldrig skal jeg - som han - paastaa: At alle de, der ikke give mig Bifald, ikke ere i stand til nogen upartisk Undersøgelse, men derimod vel istand til at indbilde sig, at to Gange tre er fem. (36 - Blichers fremhævelse) $)^{8}$

Blicher adskiller sig fra Buchholtz ved ikke at hævde at have ret. Buchholtz søger at kvalificere sig selv, Blicher at vise, hvordan hans skrift diskvalificerer sig selv, i princippet uden at have hjælp dertil behov. Buchholtz søger at finde en løsning, Blicher at finde en læsning, der kan vise det problematiske ved troen på at have fundet den endelige løsning.

Problematisering af ideologiske hierarkiseringer af modsætningspar (som f.eks. jøde/kristen), fremhævelse af en argumentations paradoksale konsekvenser, påvisning af en teksts iboende modsigelser osv. er altsammen greb, som siden er blevet associeret med dekonstruktion. I sammenhængen er de først og fremmest resultat af en tænkning, der finder det u-opbyggeligt og selvnedbrydende at tro, man ved, man har ret.

\section{"Præsten i Vejlbye"}

Dermed er vi fremme ved artiklens læsning. Handlingsforløbet i "Præsten i Vejlbye" er formentlig velkendt: Fortælleren, som er herredsfoged, dvs. på én gang dømmende og udøvende myndighed, dommer og efterforsker, skal giftes med præstens datter. Præsten anklages for mord på sin karl, Niels, og da karlens broder Morten Bruus, finder et lig nedgravet i præstens have, samtidig med at en række vidner beretter at have hørt præsten slå karlen med en spade og at have set ham grave i sin have om natten, ser fogden ingen anden udvej end at dømme præsten, som har erklæret sig for skyldig, fra livet. Præsten halshugges, og først mere end 20 år senere viser det sig, at der dermed er begået et justitsmord, og at karlen slet ikke er død. Liget tilhørte i stedet en ulykkelig tjener hos Bruus, der selv har begravet det i præstens have iført hans "Sloprok". Da herredsfogden hører dette af den tilbagevendte karl, dør han af et hjerteslag, og tragedien er fuldendt.

Fortælleren er på den ene side til det yderste moralsk. Ikke alene nægter han at lade sig bestikke i embedet og at dømme til fordel for dem, som det ville være fordelagtigt for ham at have som venner. Tillige ofrer han, da det kommer til den afgørende situation, sin egen, sin kærestes og sin svigerfaders liv og lykke for at lade retfærdigheden ske: "Ogsaa mit Hjerte vilde gjerne frikjende ham; men Følelsen tør jo ingenlunde raade over Dommerens Forstand; hverken Medynk eller Had, hver- 
ken Gunst eller Avind skal veje det mindste Gran i Retfærdighedens Skaaler" (Blicher 1829, 217f). Intet kan altså få fogden til at forlade det etiske domæne. På den anden side er han, som vi skal få at se, samtidig særdeles skødesløs i forvaltningen af sit ansvar for - juridisk og personligt - at yde præsten retfærdighed.

Fortælleren gør sin pligt, og han gør, hvad der forventes af ham. Han afhører vidner, når de bringes for ham. Han tager sin tunge gerning som dommer på sig, selv når han tvinges til at dømme, hvad han nødigst vil, og han må - kendsgerningerne og vidneudsagnene taget i betragtning - med nødvendighed nå frem til, at præsten er morderen og dømme ham til døden.

Det er, hvad han fortæller os. For læseren er der imidlertid to fortællinger; fortællerens fortælling om præsten og den herudfra konstruerbare fortælling om fortælleren. Af den anden kan vi se, at den første ikke helt er båret af den nødvendighed, som fortælleren giver indtryk af. Dertil kommer nemlig dels, hvad fortælleren ikke tilføjer, dels hvad han faktisk tilføjer. Her først i nogle hovedpunkter om betydningen af det, han ikke tilføjer:

Det afgørende punkt for afgørelsen af skyldsspørgsmålet er fundet af liget i præstens have. Fra begyndelsen kunne fogden som lovens repræsentant og efterforsker på stedet have bemærket det besynderlige $\mathrm{i}$, at Bruus ikke straks beder vidnet Jens Larsen om at udpege stedet, hvor han mener at have set præsten grave (214), hvilket allerede kunne antyde, at Bruus ikke gerne alt for hurtigt og sikkert vil kunne finde liget. Langt mere graverende er det dog, at da liget senere dukker op af jorden, undlader fogden helt og aldeles at underkaste det en grundigere undersøgelse. Blot besigtiger han, fordi han bliver bedt om det, såret i hovedet.

Endværre er hans omgang med vidnerne. De vidner, som skal sætte trumf på mod præsten, idet de vidner om at have set ham bære en sæk ind i haven om natten, er i realiteten stærke vidner for præsten (221). For hvis deres vidnesudsagn er rigtige, så har præsten hele tiden talt sandt, når han har sagt, at Niels ikke er død på stedet, men er løbet ud af haven. På et tidspunkt overvejer fogden ganske vist om ikke disse nye vidneudsagn står i modsætning til de forrige (225), men hans tanke desangående er med hans eget ord kun "flygtig". Præsten på sin side erklærer sig skyldig, ikke i vished om at have begået mord, men om under alle omstændigheder at være skyldig, nemlig i gennem sit liv at have været hidsig og have udvist vrede: "Allerede herfor havde jeg fortjent, hvad jeg nu saa sildigen maa lide" (Blicher 1829, s. 223). Mordanklagen er underordnet i forhold til den overordnede skyldighed. Det verdslige skyldsspørgsmål suspenderet til fordel for det religiøse. Stillet over for de falske anklager siger præsten blot: "Vil han i Himmelen tie, da maa jeg bøje mig under hans urandsagelige Villie" (217). Når det ikke er Guds vilje, at han skal frelses fra anklagen, vil han rette sig efter det og ikke henvise til jordisk retfærdighed og rimelighed. Han siger:

46 [...] Det ulykkelige Offer for min ustyrlige Vrede maa altsaa være faldet død om i Skoven, og jeg i min drømmende Tilstand have seet dette, og søgt ham der. Ja, Gud være mig naadig! det er - det maae være saa. (224) 
ikke alene har handlet i søvne, men også, uden at vide, hvor liget er faldet, har hentet det tilbage for at begrave det i sin egen have. Fogden burde ikke tro det.

Alt peger således i en vis forstand bort fra præsten: Han har slået, men ikke slået ihjel, men fortælleren undlader at tilføje en eneste af de slutninger eller undersøgelser, som ville kunne godtgøre det. Hvad gælder selve dommen, siger fortælleren selv, at "[...] den mildeste Dom, som baade Gud og Kongen har afsagt er dog Liv for Liv" (219), samt at "Dersom jeg ikke troede [...] at enhver Anden vilde være haardere end jeg, da skulde jeg vige mit Sæde, ja med Glæde nedlægge mit Embede”. Senere synes det at fremgå, at han kunne have dømt mildere, men ikke turde:

46 Dommen er afsagt. [...]. Nogle hvidskede endog, at den var streng [...]. Den barmhjertige Gud være mig en naadigere Dommer, end jeg Synder tør være mod mit Medmenneske! (227)

Hvad man end kan sige om dommens eventuelle hårdhed, må man som læser undre sig over, at han ikke under alle omstændigheder vælger som inhabil at vige sit sæde i den foreliggende sag. Selvom dommen ikke burde kunne lægges på én mands skuldre, ${ }^{9}$ påtager fogeden sig afgørelsen af præstens skæbne og det vel at mærke vidende, at han vil træffe en afgørelse, som i juridisk henseende ikke kan falde meget værre ud for præsten.

Udfaldet af denne afgørelse er et resultat af mødet mellem anklageren Morten Bruus, som er opfindsomhed uden moral og fortælleren og dommeren, som er moral uden opfindsomhed. Morten Bruus formår at invadere, okkupere og applikere fortællerens tankegang og sprog. F.eks. er Bruus' ord "Vi har jo Lov og Ret i Landet" (210) et til mindste detalje nøjagtigt ekko af fortællerens (207), mens fortællerens ordvalg om præsten senere er dybt prægede af Bruus'.

I samme bevægelse, som han påtager sig dommen over præsten, fralægger fortælleren sig ansvaret for aktivt at kvalificere afgørelsen af, hvad præsten er, ved bestandigt i stedet at henvise til andre instanser. Han tror på vidnerne, på præsten, endog på Bruus og undlader helt at undersøge for i stedet hele tiden at gøre, hvad han tror, der forventes af ham.

I modsætning til præsten suspenderer han hverken det verdslige skyldsspørgsmål eller sit embede som verdslig dommer, men derimod kravet om en handlende forvaltning deraf. Fortælleren tager diktat i stedet for at fortolke, og vælger dermed et retfærdighedens bogholderi.

Hvad fortælleren ikke tilføjer, er således en historie i sig selv, som man let kan overse, men dertil kommer som nævnt, hvad han tilføjer:

Det gælder både ved liget og ved den gravende, at der sluttes fra klæder til identitet. Ved ligfundet lyder det således:

6f Snart var hele Liget udgravet - det var virkelig den Savnede. Hans Ansigt var ikke ganske kjendeligt, da det var begyndt at gaae i Forraadnelse og Næsebenet desforuden knuset og fladtrykt; men alle hans Klæder, lige til Skjorten med hans udsyede Navn, kjendtes straks af alle hans Medtjenere; endogsaa en Blyring i det venstre Øre vedkjendtes af alle de Omstaaende som Niels Bruuses [...]. (214f.) 
For en retrospektiv betragtning er det ganske tydeligt, at kun ydre ting som tøjet og ringen udpeger den døde som Niels, men herredsfogden tilføjer alle de manglende slutninger. Det samme gælder ved det hul i hovedet, som han kaldes hen for at besigtige, og hvorom han siger, at det "[...] kjendeligen viste sig at være bibragt ved en Spade, eller et saadant sløvt Redskab” (216). Herredsfogden binder vidnesudsagnene og kendsgerningerne sammen og forbinder dem med hinanden ved at tilføje det, der mangler, for at de kan passe i en ramme, hvor præsten er morder.

Meget tidligt omtaler han Morten Bruus som "den skrækkelige Blodhævner" (214), et udtryk som direkte implicerer, at præsten er morder. I dagbogen optræder udtrykket lige ved Bruus': “[...] bie lidt, Broder Niels! Hævn skal du faae!” (214), og her som så mange andre steder er fogdens ordvalg og domme påvirkede af omgivelsernes og ikke mindst af Bruus'. Allerede inden sagen mod præsten er begyndt, og mens der med fortællerens egne ord er tale om "Mistanke" (209), skriver han i sin dagbog, at hans kærestes far er i fængsel "[...] som en Morder og Misdæder!" (209). Tilsvarende omtaler han, før han så meget som har kastet et blik på liget, den døde som "den Dræbte" (215).

Allermest sigende i den sammenhæng er måske hans replik, da præsten mod slutningen beder ham skelne mellem mundens og hjertets dom:

ff [...] jeg veed, at eders Mund skal fordømme mig; men hvad siger eders Hjerte?” "Mit Hjerte!" svarte jeg - det var knap jeg for beklemmelse kunne tale - "mit Hjerte lider usigeligt, og vilde gjerne briste i dette Øjeblik, naar det derved kunde frelse Eder fra en skrækkelig og vanærende Død -". (225)

"Skrækkelig og vanærende", det er hjertets dom, og med den dom som ramme dømmer Herredsfogden præsten med sin fortælling, længe før han dømmer ham som dommer. Fortælleren er bestandig så opmærksom på, hvad andre tænker og fortæller om ham, at hans fortælling om, hvordan kendsgerningerne er, determineres af hans opfattelse af, hvad præsten er, nemlig morder, frem for omvendt.

I "Præsten i Vejlbye" begår fortælleren og fogden justitsmord og berøver derved præsten livet og adskillige mennesker lykken. Han er på én gang ven med og dommer for præsten. I netop disse roller kan han anklages for til stadighed at optræde i objektiv overensstemmelse med loven, men uden subjektiv agtelse for loven; for at handle pligtskyldigt, men uden opfindsomhed. Han er " $\mathrm{i}$ ly for kritik, under rettens beskyttelse, [...] i overensstemmelse med den objektive ret, men [...] ikke [...] retfærdig" (Derrida 2007a, 226). Denne pointe understreges i øvrigt kraftigt af, at han gerne vil hjælpe præsten til at flygte (Blicher 1829, 227 et passim). Når han derimod ikke vil bøje loven eller dømme mildt, så synes det netop at være fordi, han er i lovens, men ikke en højere retfærdigheds tjeneste. 


\section{Læseren og griberen i rugen}

Ved at tolke teksten således og med de ovenstående anklager mod fortælleren in mente synes læsningen at ende i den konklusion, som er fortællerens egen første:

Saa er jeg nu [...] uværdigen forfremmet til Herredsfoged og Dommer over dette Folk. (201)

Karakteristikken af sig selv som uværdig er den rigtigste, fortælleren overhovedet fremsætter, fristes man til at sige. Men yder man som læser fortælleren og teksten retfærdighed ved at vise, at han ikke yder præsten retfærdighed?

Fra et retorisk og etico-narratologisk synspunkt som James Phelans er fortællinger privilegerede steder for etisk refleksion, og afgørende i den sammenhæng er netop spørgsmålet om læserens "position":

4 Faktisk er den centrale konstruktion i vor tilgang til læsningens etik begrebet position, som kombinerer handle ud fra og bliven placeret $i$ en etisk lokalitet. (Phelan og Martin 2004, 159f)

Phelans og Martins (som er medforfatter på ovennævnte artikel) hovedeksempel er Resten af dagen af Ishiguro:

46 Når læsningens etiske dimension engagerer vore værdier og domme, er den dybt sammenflettet med kognition, emotion og begær [...]. Således vil det at komme til rette med de etiske dimensioner i den diskrepans, der består mellem Stevens' fortællen og hans handlen $[\ldots .$.$] indebære, at vi konfronterer følgende indbyrdes sammenhængende spørgs-$ mål: Skulle Stevens have talt anderledes til Miss Kenton [...]? Hvordan fører Ishiguro os til et svar på det spørgsmål [...]? Hvad er konsekvensen af, at vi atter er i en vidensposition, hvor vi ved mere end karaktererne og deres situation end de selv ved? De [...] tre spørgsmål viser, hvor dybt sammenflettet karakterens, fortællerens og den implicitte forfatters etiske positioner er: At besvare ét implicerer et svar på de andre. (Phelan og Martin 2004, 159f)

Phelan og Martin foretager således deres læsninger og teoriudvikling på baggrund af en antagelse om, at teksten placerer læseren i en position, hvor hun skal træffe etiske valg eller domme over for karaktererne, fortælleren, the implied author og tekstens værdier. Læseren bliver placeret i en etisk position ved at skulle forhandle forskellige mulige svar på de tre spørgsmål, som de i øvrigt gør en pointe ud af, at de hver for sig ville besvare forskelligt.

I forhold til "Præsten i Vejlbye" er det i den sammenhæng værd, som Claus Esmann Andersen gør det i sin læsning (Andersen 2004, 109), at henlede opmærksomheden på, at fogden selv føler sig stillet for en dommer. Først siger han om vidnerne:

6 I Morgen møde de på Thinget; jeg er tilmode, som om det var imod mig selv, de skulde vidne. (Blicher 1829, 221) 
Og straks efter i enrum med præsten:

4 Endelig rettede han sig op, og hæftede sine Øjne paa mig: jeg ventede i ængstelig Taushed, som om jeg skulde høre min egen Dom - ja, paa en Maade skulde jeg jo ogsaa. (222)

Ved som dommer at stille sig selv til doms skaber fortælleren selv en sammenhæng mellem sine domme og dommen over ham - det være sig Guds, præstens eller eftertidens læsere af dagbogen.

I Blichers fortælling må man derfor i første omgang se, at når Blicher i forhold til den virkelige sag indfører fortælleren, sættes der fokus på bedømmelsen af fortælleren frem for på dommen over præsten. Men i og med denne forskydning, opdager læseren i anden omgang, sættes der ligeledes fokus på bedømmelsen af fortælleren frem for på dommen over præsten.

Problemstillingen bliver dermed, at læseren ved at dømme fortælleren vanskeligt undgår at finde sig selv på præcis den plads, som fortælleren før besad.

Læseren bliver i en meget bogstavelig forstand sat i dommerens sted, ja, mere end det; læseren sættes i en position, hvor hun, hvis hun dømmer, at fortælleren dømmer sig selv med sin dom, må være parat til ud fra samme logik at dømme sig selv med denne sin dom. I denne struktur ligger ingenlunde et banalt krav om frikendelse. Tværtimod ville en frikendelse være en dom ligefuldt.

Phelans og Martins begreber om "position" og "bliven placeret $i$ en etisk lokalitet", som citeret ovenfor, er her tilføjet en dimension. Ikke alene er der tale om, at "læsningens etiske dimension engagerer vore værdier og domme", som de skriver; læseren finder sig selv impliceret netop for så vidt angår de etiske spørgsmål, som teksten rejser.

Læseren stilles over for Blichers tekst i en uundslippelig position, hvor hun selv må lægge hovedet på blokken og derfor risikere at optræde hovedløst, hvis hun lader sværdet falde. Hun kan dømme eller frikende, men ikke stille sig uafficeret uden for dommen. Fortællingen skaber en nødvendig sammenhæng mellem fortællerens tolkninger og domme og læserens tolkninger og domme. Spørgsmålet om retfærdighed lader sig ikke besvare og lader sig ikke ikke besvare. Det er kun muligt som umuligt.

Men vi kan komme det lidt nærmere end som så.

I dag, hvor man taler om en film som gribende; om hvor grebet man var under læsning osv., er gribemetaforen en stort set død metafor. Men i Kierkegaards gentagne og varierede brug af ordet om Blicher ligger der en indsigt, som jeg har forsøgt at låne. Kierkegaard siger både om hedepræsten, at han har "[...] grebet, hvad jeg har sagt, og hvad jeg gjerne vilde have sagt" (Kierkegaard 1843a, 310) og om Blichers noveller, at de nødvendigvis må gribe samtiden. Det er værd at bemærke, at verbet gribe anvendes på to helt forskellige måder, men at Blicher i begge tilfælde er den aktive. I det første tilfælde modtagende aktiv, i det andet tilfælde indfangende aktiv. Den indfangen eller positionering af læseren, som finder sted i "Præsten i Vejlbye" er, tror jeg, resultatet af en omhyggelig konstruktion fra Blichers side. Læseren må "nødvendigviis" lade sig "gribe" af Blichers tekster, som Kierkegaard 
gør opmærksom på. Dermed opklares også den tilsyneladende eklatante selvmodsigelse, som Kierkegaards postulat om, at enheden i novellerne "nødvendigviis maa gribe Samtiden meget mere, end den har gjort", synes at rumme, idet man kunne spørge, hvorfor "nødvendigviis", hvis den netop endnu ikke har gjort det. Betragter man imidlertid ordene som en karakteristik af en strukturel nødvendighed ved fortællingernes konstruktion, og ikke (nødvendigviis) af en faktisk omstændighed i læsningen, er der imidlertid ingen modsigelse. I så fald kan de netop læses i sammenhæng med den bemærkelsesværdige karakteristik, som de optræder ved siden af; som et resultat af "Umiddelbarhedens Taageslør" (Kierkegaard 1838, 28). Det tager sig så enkelt ud, at man først for sent opdager, at man er blevet indfanget.

I kastespillet mellem Blicher og Kierkegaard er der en bevægelse begge veje, men (i Kierkegaards beskrivelse) med Blicher som primus motor: Kierkegaard er grebet af Blichers noveller, og Blicher griber, hvad Kierkegaard vil sige (eller hvad de silentio ikke kan sige).

\section{Hinsides økonomi eller en økonomi hinsides}

Modstillingen af det almene og det absolutte og kravet om overskridelsen af pligten vil aldrig kunne placere sig inden for etikkens eget domæne og vil aldrig kunne basere sig på sikkerhed. Hvordan vide, om man er Abraham eller Ohlendorf; om man er opfindsom eller forsømmelig? Det må nødvendigvis forblive et spørgsmål om tro, og det er også med det spørgsmål, at Dødens gave slutter, idet Derrida citerer Nietzsches spørgsmål, om det er muligt at tro på den radikale overskridelse af ethvert kendt $\varnothing$ konomisk princip, der ligger i Jesus' ofring, hvor han går hinsides skyld og gæld ved at give sig selv i betaling for sine skyldnere (Derrida 2007b, 131).

I "Præsten i Vejlbye" finder man mindst to, helt forskellige suspensioner af det etiske, nemlig fortællerens og præstens. Her kan man hente et korrektiv til både den pligtmæssige regelforvaltning og den religiøse suspension af pligt. Præsten suspenderer det verdslige til fordel for det religiøse, og fortælleren lader sine mange Gudspåberåbelser tjene som en apologi for ikke selv at handle. "Hver Mands Dom kommer af Herren." citerer han allerede i første dagbogsoptegnelse (201). Men domme - i det mindste dennesidige sådanne - kommer ikke fra Herren, viser teksten tydeligt. Vi kan blive påvirket af løgne, bedrag og af "Belials" mænd. Hverken den dom, man afsiger, eller den, som afsiges over én (med en eksplicitering af dobbeltheden i udtrykket) i dette liv, kommer af Herren. Herrens dom findes kun hinsides, hvilket stemmer godt overens med Blichers ord i prædikenen om, at mennesket selv er ansvarligt for hvad godt og ondt, det bedriver i denne verden. Præstens datter siger til afsked til fogeden: "[...] I gjorde kun eders strenge Pligt [...]" (Blicher 1829, 228) og anslår med det tvetydige udtryk den pointe, som Derrida ekspliciterer, at hvis man kun har gjort sin pligt og ikke mere, så har man ikke gjort sin pligt.

I "Lovkraft" siger Derrida i direkte forlængelse af citatet oven for om, at dekonstruktion i virkeligheden altid har handlet om retfærdighed, altid har gjort det indirekte: 
64 Dét er, hvad jeg gerne vil bestræbe mig på at gøre her: vise, hvorfor og hvordan det, man plejer at kalde dekonstruktionen, som tilsyneladende ikke beskæftiger sig med retfærdighedens problem, faktisk ikke gør andet, men uden at kunne gøre det direkte, kun på en oblik facon. (Derrida 2007a, 213)

Derrida opstiller senere i "Lovkraft" tre aporier for retfærdighed (s. 236, 238, 242). De to første; "Epoché af reglen" og "Det uafgørliges spøgelse" minder en del om hinanden. En dom kan ikke blot følge regler, men må også affirmere og konfirmere dem (236), og en dom kan ikke være retfærdig, hvis den ikke følger regler, men heller ikke hvis den blot følger regler (238f). Den tredje "Den uopsættelighed, der spærrer videnshorisonten" har at gøre med, at retfærdighed må ske omgående eller så hurtigt som muligt og ikke vedblivende kan afvente mere information. Den må derfor altid på et tidspunkt lave et snit og en afgørelse, der bortskærer al resterende oplysning, viden, kontekst m.m., som er relevant for spørgsmålet om retfærdighed.

Konklusionen på de tre aporier bliver for Derrida, at hvis retfærdighed må ske, så er det med nødvendighed måske:

4 "Måske", man må altid sige må-ske om retfærdighed. Der findes en kommen for retfærdigheden, og der findes ikke retfærdighed, uden i det omfang, den begivenhed er mulig, der som begivenhed går ud over kalkulen, reglerne, programmerne, anticipationerne etc. (246)

I Blichers fortælling går der hele 21 år fra præsten henrettes, til sandheden kommer for en dag. Det lange tidsrum synes symptomatisk for det forhold, at spørgsmålet om retfærdighed aldrig med sikkerhed kan anses for afgjort. Eller som det hedder i præstens egen prædiken: "Priis Ingen lykkelig, før hans Endeligt kommer!" (Blicher $1829,224)$. Det kan altid nå at vise sig, at man tog fejl, at man dømte sig selv. Kort fortalt: at man ikke havde ret.

Argumentationsgangen, som jeg har søgt at gøre gældende, er således, at:

- i Enten-Eller fremstilles prædikenen om det opbyggelige ved tanken om at have uret for Gud som en tekst, der har Blicher som forfatter.

- Senere samme år stiller Kierkegaard i Frygt og Bæven spørgsmålet som en religiøs, teleologisk suspension af det etiske.

- I sin Kierkegaard-læsning radikaliserer (eller afradikaliserer, alt efter smag) Derrida dette spørgsmål som et generelt spørgsmål om den enkeltes pligt til at overskride pligten og det almene.

- Dermed bringes tolkningen af Kierkegaard faktisk tættere på Blichers "uretstænkning", både generelt i prædikener og andre tekster og i "Præsten i Vejlbye" specifikt, end på den religiøsitet, som de silentio ikke kan forstå hos Abraham.

- "Præsten i Vejlbye" imødegår den indre modsigelse i at bringe læseren frem mod en erkendelse af det opbyggelige ved ikke at have ret ved at fremstille spørgsmålet om ret og uret og om pligt og pligtens overskridelse på både et tematisk og et strukturelt niveau i læserens møde med teksten. 
raliserer i hver sin retning, så tillader de tilsammen at se, hvordan novellen som en litterær eksegese af "dømmer ikke" er opbyggelig, ikke på trods, men på grund af, at den ikke bringer læseren frem til muligheden for en retfærdig mening og position, men lader ham gribes af tro og tvivl.

I "Præsten i Vejlbye" kan man let overse, at også præstens og hans suspension er omfattet af den dom, som novellen med Aalsøe-præstens afsluttende ord fælder over snart sagt alle sine aktører:

46 Og blev det mig altsaa klart, hvorlunde min ulykkelige Medbroder var falden som et Offer for den nedrigste Ondskab, for sin Dommers og for Vidnernes Forblændelse, og for sin egen lettroende Indbildningskraft. (s. 234)

"Ondskab", "Forblændelse" og "lettroende Indbildningskraft" har ført til to suspensioner af det etiske og til en tragedie. Det forbliver et åbent spørgsmål, om der var andre muligheder, og om fortælleren kunne have optrådt retfærdigt ved at være opfindsom frem for alene pligtmæssigt at handle og dømme efter regler og paragraffer. Konstruktionen af "Præsten i Vejlbye" er nødvendig både for at gøre denne "rette" suspension af pligten til en potentiel mulighed frem for en aktualiseret realitet, og for at spørgsmålet om ret ikke - i denne aktualisering - bliver til en forvisning om at have truffet det korrekte valg, men et vidnesbyrd om urettens vilkår og opbyggelighed.

Fælles for den pligt til overskridelsen af pligten, som Derrida ser som et alment etisk vilkår, for Abraham i Kierkegaards tolkning og for den opbyggelighed ved uret over for Gud, som fremstilles i "Ultimatum", er umuligheden af en henvisning til viden, almene principper eller regler og sikkerhed. I alle tilfælde er der tale om radikale "leaps of faith", hvor man aldrig vil kunne sige "jeg er retfærdig" eller "jeg har ret".

Med Derrida kan vi bl.a. se, at ret, i den logik der hersker i "Ultimatum", i Blichers prædiken og i specielt "Præsten i Vejlbye", ikke uden at blive selvmodsigende kan falde tilbage i noget, man kan være sikker på at have. Ret er en gave, noget man kan give og håbe at blive givet.

Derrida bevæger sig i sin læsning af Kierkegaard fra spørgsmålet om en umedierbar modsætning mellem det etiske og det religiøse til en umedierbar modsætning $i$ det etiske. Spørgsmålet er ikke alene, om der gives en teleologisk suspension (i religiøs forstand) af det etiske, men hvad det betyder, at en teleologisk suspension af det etiske med nødvendighed er iboende det etiske selv.

Spørgsmålet er, om Derrida ville kunne have gjort dette, hvis ikke Kierkegaard var blevet grebet af Blicher og af den tågeslørets umiddelbarhed, som ligger i den hos Blicher stadigt gentagne indsigt, at enhver menneskelig formening om med sikkerhed at have ret på én gang er religiøst anskuet ukristen og etisk set selvdestruerende.

Jeg vil gerne takke Poul Behrendt, Jacob Bøggild og Joakim Garff for gennemlæsning og nyttige kommentarer til artiklen. 


\section{Noter}

I Det gælder helt særligt James Phelan, der trækker "etik" frem i titlen på så vigtige tekster som Narrative as Rhetoric: Technique, Audiences, Ethics, Ideology, 1996, Ohio State University Press, "Homodiegesis, upålidelighed, etik og Resten af dagen" (2004), in Henrik Skov Nielsen og Stefan Iversen (red.): Narratologi, samt Living to Tell About It: a Rhetoric and Ethics of Character Narration, 2004, Cornell University Press.

2 Jeg refererer til og citerer fra den engelske tekst. Artiklens første halvdel, som det her handler om, blev som foredrag holdt første gang på engelsk, og Derrida gør i foredragets første sætning en pointe ud af netop dette forhold.

3 Der er i det hele taget mængder af lån af ord, tanker og formuleringer forfatterskaberne imellem. Kierkegaard henter $\mathrm{fx}$ aldeles ordret den markante formulering "Stormene have udraset", der indleder optegnelsen i Gjentagelsen fra d. 13. januar (Kierkegaard 1843b, s. 181) fra en tilsvarende dagbogsoptegnelse af Eneboeren på Bolbjerg (Blicher 1834, s. 147).

4 Langballe nævner bl.a. ordet "Kornmod" og Sub Rosa-digtet, men knytter ingen betragtninger til digtet. Det vil straks fremgå både hvor jeg er uenig med Langballe, og hvad jeg ellers har at tilføje.

5 For en god og nuanceret bestemmelse af karakteren af Blichers egen senere mulige antisemitiske drejning se Kjærgaard 2007.

6 Skriftet indeholder generaliseringer som: "Vil man i en almindelig Formel angive Differentsen mellem Jøde og Christen, saa maa man sige: Jøden elsker Livet for Penges Skyld, den Christne derimod Penge for Livets Skyld" (Buchholtz, 211), samt utallige passager som denne: "Al Had til Jøder vilde i sig selv ikke finde Sted, var ikke den Forudsætning altid mer eller mindre grundet, at Jødernes Rigdom er Resultatet af de fuleste og foragteligste Aager-Kunster" (208f).

7 Blicher citerer korrekt nok, men angiver ikke sidetal. Citatet findes i Buchholtz' fortale s. III.

8 Blicher angiver s. 103 som kilde til citatet. I den version, jeg citerer fra, optræder det s. 266.

9 Jf. moralen i fortællerkommentaren mellem A og B samt Aalsøe-præstens kommentar til slut: "just denne tragiske Begivenhed gav Anledning til, at Delinqventsager for Eftertiden blive foretagne ved alle Instantserne" (228).

“Ak! Hvad er dog et Menneske, at det tør opkaste sig til Bloddommer over sin lige? Hvo tør sige til sin Broder, Du est skyldig at døe?" (234).

\section{Litteratur}

Andersen, Claus Esmann (2004): Det tragiske i moderne prosadigtning (upubl. ph.d.-afhandling). Attridge, Derek (1999): "Innovation, Literature, Ethics" in Culler, Jonathan (2003): Deconstruction. Critical Concepts in Literary and Cultural Studies, vol. I-IV, New York, Routledge.

Attridge, Derek (2004): The Singularity of Literature, London \& New York, Routledge.

Blicher, Steen Steensen [1813]: "Bedømmelse over Skrivtet Moses og Jesus” in Samlede Skrifter, 3, Nordisk Forlag, København 1920.

Blicher, Steen Steensen [1829]: "Præsten i Vejlbye" in Noveller og Digte, 1, Det danske Forlag, København 1943.

Blicher, Steen Steensen [1834]: "Eneboeren på Bolbjerg" in Samlede Skrifter, 19, Nordisk Forlag, København 1927.

Blicher, Steen Steensen (1839): "Skytten paa Aunsbjerg" in Kornmod

Blicher (1846 [1840]): "Erindringer af Steen Steensen Blichers Liv, optegnede af ham selv" in Gamle og nye Noveller, Kjøbenhavn. 
Blicher, Steen Steensen (1920): Samlede Skrifter, København, Nordisk Forlag.

Wayne C. Booth (1988): The Company We Keep: An Ethics of Fiction, Los Angeles, University of California Press.

Bucholtz, Friedrich (1813): Moses og Jesus, Kiøbenhavn.

Derrida (1995 [1992]): The Gift of Death, London, University of Chicago Press.

Derrida (2002 [1990]): "Force of Law" in Acts of Religion, Routledge, New York.

Derrida (2007a [1990]): "Lovkraft” in Lov og litteratur, Aarhus Universitetsforlag, Århus.

Derrida (2007b [1992]): Dødens gave, København, Anis.

Kant, Immanuel (1974 [1787]): Kritik der praktischen Vernunft, Hamburg, Felix Meiner Verlag.

Kierkegaard, Søren [1838]: Af en endnu Levendes Papirer in Samlede værker, 1, København, Gyldendal, 1962.

Kierkegaard, Søren [1843a]: Enten-Eller in Samlede værker, 2 og 3, København, Gyldendal, 1962.

Kierkegaard, Søren [1843b]: Gjentagelsen in Samlede værker, 5, København, Gyldendal, 1962.

Kierkegaard, Søren [1843c]: Frygt og bæven in Samlede værker, 5, København, Gyldendal, 1962.

Kierkegaard, Søren (1968): Søren Kierkegaards Papirer, 2, København, Gyldendal.

Kjærgaard, Christoffer (2007): Dansk-jødisk tilstedeværelse (upubl. speciale).

Langballe, Jesper (2004): Anlangendes et menneske, Odense, Syddansk Universitetsforlag.

Littell, Jonathan (2008): De velvillige, København, Gyldendal.

Newton, Adam (1995) Narrative Ethics, Cambridge, Harvard University Press.

Nielsen, Henrik Skov og Stefan Iversen (red.) (2004a): Narratologi, Århus, Aarhus Universitetsforlag.

Nielsen, Henrik Skov og Stefan Iversen (red.) (2004b): Dekonstruktion, Århus, Aarhus Universitetsforlag.

Nielsen, Henrik Skov (2005): "I dækning - om drab, dåb og dækket, direkte tale i "Skytten på Aunsbjerg"' in Cramer, Jens et al. (red.): Teorien om alt, Wessel og Huitfeldt.

Phelan, James (1996): Narrative as Rhetoric: Technique, Audiences, Ethics, Ideology, Ohio State University Press.

Phelan (2004): "Homodiegesis, upålidelighed, etik og Resten af dagen" in Nielsen og Iversen 2004a.

Phelan (2005): Living to Tell About It: A Rhetoric and Ethics of Character Narration, Cornell University Press. 